\title{
The Effect of Active Immunization of Ewes against Androstenedione on Lambing Rate and Production
}

\author{
By K. Sivesindtajet, $\varnothing$. Andresen and K. Karlberg
}

Department of Reproduction and Forensic Medicine, Norwegian College of Veterinary Medicine, Oslo, Norway.

\begin{abstract}
Sivesindtajet, K., Ø. Andresen, and K. Karlberg: The effect of active immunization of ewes against androstenedione on lambing rate and production. Acta vet. scand. 1989, 30, 431-435. - Active immunization of sheep of the Dala breed against androstenedione caused a mean increase in number of lambs born (liveborn and stillborn) of $0.29(p<0.01)$. In yearlings the difference was 0.43 lambs ( $p$ $<0.01$ ) and in older ewes 0.23 lambs $(p<0.1)$. Five of the older immunized ewes gave birth to quadruplets while none in the control group gave birth to more than 3 lambs. In older ewes there was an increase in the number of stillborn lambs. In young immunized ewes the mean ewe production, registered as total live weight of lambs in the autumn, was $11.3 \mathrm{~kg}$ higher than in control animals. This difference was however not significant $(\mathrm{p}<0.1)$.
\end{abstract}

lambs born; lamb crop.

\section{Introduction}

Immunization against different steroids influences the fecundity of ewes (for review see Smith 1985). Active immunization against adrostenedione has been found to increase the ovulation rate (Scaramuzzi et al. 1977). A mean increase in ovulation rate of about $37 \%$ has been reported in immunized animals relative to the mean of controls (Hanrahan \& Quirke 1987), and an extra 20-40 lambs born per 100 ewes mated has been reported (Geldard et al. 1984).

Two possible mechanisms by which circulating androstenedione-antibodies may influence ovarian activity have been proposed by Scaramuzzi (1979). Neutralization of the biological effects of androstenedione by its antibodies, could interfere with negative feedback of steroids on the hypothalamo-pituitary axis and lead to elevated levels of gonadotropins in the circulation and thus to an increase in the development of follicles in the ovaries. An alternative explanation relate to the local effect of androgens in the ovaries as androgens seem to be involved in the atresia of follicles. In ewes immunized against androstenedione, follicular atresia could be reduced, and more follicles stimulated to ovulate.

The present study was undertaken to obtain information on the effect of immunization against androstenedione of ewes under Norwegian management conditions, and especially to study the effect of immunization on the number of lambs born and total lamb crop from young ewes, i.e. ewes about 1 year old at the time of lambing.

\section{Material and methods}

\section{Animals}

The study was performed in 4 herds. The material comprised 208 ewes of the Dala breed. A total of 95 ewes were immunized and 113 served as controls. Among immuni- 
zed animals 22 were young ewes, about 6 months old at the time of immunization, while 73 were older animals. Corresponding figures for control animals were 27 and 86 ewes, respectively.

\section{Immunization}

The ewes were immunized 8 and 4 weeks before intended mating with $2 \mathrm{ml}$ of a solution of an androstenedione-protein conjugate and an immuno-adjuvant ${ }^{1)}$. The injections were given subcutaneously in the neck. No injections were given to the control animals.

\section{Registration}

Abortions in the flocks were registered, as were the number of live and stillborn lambs. A few weeks following lambing the animals were sent on pasture in the mountains. Returning to the farm in the autumn the number of lambs as well as lamb weights and the total lamb crop per young ewe were registered.

\section{Statistical analyses}

Statistical analyses were performed using analysis of variance and chi - square tests, i.e. the GLM and FREQ-chisquare procedure from Statistical Analysis System. The number of lambs (born and by the end of the grazing season) and total lamb crop from young ewes, were evaluated by linear models which accounted for the effects of treatment. The success-probabilities of specific numbers of lambs born in the treatment and control group were evaluated by chi-square tests. $\mathrm{p}<0.05$ was taken to represent statistical significance.

\footnotetext{
1) The preparation (called Multilamb or Fecundin), was kindly made available by Coopers Animal Health Ltd., (Berkhamsted Hill, Berkhamsted, Herts HP4 2QE, England).
}

\section{Results}

Five older ewes aborted; 2 of the immunized animals and 3 of the controls.

The mean total number of lambs born (liveborn and stillborn) by the immunized animals was 2.14 , while the corresponding mean for the control group was 1.85 ( $\mathrm{p}$ $<0.01$ ). The lambing rate in young ewes and older ewes differed. The lambing rate of young immunized ewes was significantly higher than that of the control group, 1.73 lambs and 1.30 lambs, respectively ( $p$ $<0.01$ ). Also in older ewes there was a strong tendency towards a higher lambing rate in immunized animals than in the control group ( $\mathrm{p}<0.1)$ (Table 1$)$.

A significantly higher number of immunized older ewes, compared with older control ewes, gave birth to more than 2 lambs ( $p$ $<0.05$ ). Among the immunized older ewes, 5 had quadruplets while none of the ewes in the control group had quadruplets. The difference was significant $(p<0.05)$. Two of these ewes, as well as their lambs died during a complicated parturition. In addition to these 2 ewes, 9 other older ewes gave birth to a total of 12 stillborn lambs. Among these a set of triplets was stillborn and further a single lamb in 6 sets of triplets. Among older ewes in the control group only 1 ewe had a stillborn lamb. Thus in older immunized ewes there was a strong increase in the number of stillborn lambs. Among the young ewes there was 1 stillborn lamb in each group.

The results of the registration among young ewes after the pasture season are given $\mathrm{i}$ Table 2. A difference of 0.36 lambs between immunized and control young ewes ( $p$ $<0.05$ ) was found.

The mean lamb crop in immunized young ewes was $11.3 \mathrm{~kg}$ higher than in control animals. This difference was however not significant $(\mathrm{p}<0.1)$. 
Table 1. Total number of lambs born (alive and stillborn) by androstenedione-immunized and control ewes.

\begin{tabular}{|c|c|c|c|c|c|c|c|c|}
\hline \multicolumn{3}{|c|}{$\begin{array}{l}\text { Ewes giving } \\
\text { birth }\end{array}$} & \multirow{3}{*}{$\begin{array}{c}\begin{array}{c}\text { No. of lambs } \\
\text { born per ewe } \\
\text { Mean } \pm S D\end{array} \\
1.73 \pm 0.63^{\mathrm{a}}\end{array}$} & \multicolumn{5}{|c|}{$\begin{array}{c}\text { No. of ewes with } \\
\text { 1-4 lambs }\end{array}$} \\
\hline & & & & \multirow{2}{*}{$\begin{array}{l}1 \\
8\end{array}$} & \multirow{2}{*}{$\frac{2}{12}$} & \multirow{2}{*}{$\begin{array}{l}3 \\
2\end{array}$} & \multirow{2}{*}{$\begin{array}{l}4 \\
0\end{array}$} & \multirow{2}{*}{$\frac{\text { Total }}{38}$} \\
\hline Immunızed & Young ewes & $\mathrm{n}=22$ & & & & & & \\
\hline animals & Older ewes & $\mathrm{n}=71$ & $2.27 \pm 0.86^{c}$ & 14 & 29 & 23 & 5 & 161 \\
\hline & Total & $\mathrm{n}=93$ & $2.14 \pm 0.84^{e}$ & 22 & 41 & 25 & 5 & 199 \\
\hline & Young ewes & $n=27$ & $1.30 \pm 0.47^{b}$ & 19 & 8 & 0 & 0 & 35 \\
\hline animals & Older ewes & $\mathrm{n}=83$ & $2.04 \pm 0.61^{d}$ & 14 & 52 & 17 & 0 & 169 \\
\hline & Total & $\mathrm{n}=110$ & $1.85 \pm 0.66^{f}$ & 33 & 60 & 17 & 0 & 204 \\
\hline
\end{tabular}

Level of significance:

a-b: $p<0.01$

c-d: $p<0.1$ n.s.

e-f: $p<0.01$

Table 2. Number of lambs born by young ewes immunized against androstenedione and their lamb crop registered after the grazing season.

\begin{tabular}{lcl}
\hline & $\begin{array}{c}\text { Immunized ewes } \\
(\mathrm{n}=22) \\
\text { Mean } \pm \mathrm{SD}\end{array}$ & $\begin{array}{c}\text { Controls } \\
(\mathrm{n}=27) \\
\text { Mean } \pm \mathrm{SD}\end{array}$ \\
\hline Lambs born per ewe & $1.73 \pm 0.63^{\mathrm{a}}$ & $1.30 \pm 0.47^{\mathrm{b}}$ \\
Lambs returning from pasture/ewe & $1.32 \pm 0.65^{\mathrm{c}}$ & $0.96 \pm 0.59^{\mathrm{d}}$ \\
Weight of lambs after pasture $(\mathrm{kg})$ & $36.2 \pm 7.2^{\mathrm{e}}$ & $37.9 \pm 6.1^{\mathrm{f}}$ \\
Lamb crop per young ewe $(\mathrm{kg})$ & $47.8 \pm 20.7^{\mathrm{g}}$ & $36.5 \pm 20.3^{\mathrm{h}}$ \\
\hline
\end{tabular}

Level of significance:

a-b: $p<0.01$

c-d: $p<0.05$

e-f: $p<0.1$ n.s.

g-h: $p<0.1$ n.s.

\section{Discussion}

The mean number of lambs born per ewe in the county where the study was performed was 1.72 lambs for older ewes and 0.87 for young ewes, respectively (Anonymous 1987). The control animals in the present study gave birth to a mean of 1.85 lambs, with 2.04 and 1.30 lambs born in older and young ewes. Thus, the number of lambs born in the farms participating in this study was somewhat higher than average for the county.

In the total material the lambing rate was significantly higher in immunized animals ( $p$ $<0.01)$. When looking at the different age groups i.e. ewes about 1 year old, and ewes 2 years or older, it became apparent that although the lambing rate was numerically 
higher both in older and younger immunized ewes, the difference between immunized and control animals was significant only in young ewes. In young ewes immunization against androstenedione appeared to increase the number of lambs born with about 0.4 lambs per ewe. Although not significant, there was also a strong tendency towards an increase in lambing rate among the immunized older animals. In immunized ewes, 6 months to 7 years of age a similar increase in ovulation rate has been recorded (Geldard 1984), without any effect of age on the number of extra born lambs in the range of 18 months to 7 years.

In older immunized ewes there was a strong increase in the number of stillborn lambs. In the present study no positive effect of immunization of older ewes could thus be registered. In immunized young ewes no increase in the number of stillborn lambs was noticed. Breeding of young ewes, 7-8 months old, is very common in Norway. Nearly $70 \%$ of one year old ewes lamb, with a variation between counties from 47 to $91 \%$ (Anonymous 1987). Opinions differ as to whether young ewes should have 1 or 2 lambs. When young ewes have twins, the lambs are smaller and the lambing might be easier. However nursing 2 lambs puts a heavier stress on the udder with a possible increase in the occurrence of mastitis.

The difference in number of lambs per young ewe remained significant when the animals returned from pasture in the autumn. This indicates that the young ewes were able to take care of the increased number of lambs. Although the difference in mean lamb crop per young ewe was $11.3 \mathrm{~kg}$, this difference was not significant ( $\mathrm{p}<0.1)$.

Geldard et al. (1984) found that immunization against androstenedione did not alter the normal distribution of litter size. The effect of immunization appeared to be compa- rable to the effect of flushing or genetic methods such as crossbreeding. Smith (1985) also found that both the proportion of twins, triplets and quadruplets increased following immunization. In the present study immunization of older ewes was followed by an increase in the number of ewes with triplets and quadruplets. In the control animals no ewe had quadruplets while 5 ewes among the immunized animals had 4 lambs. Quadruplets are considered very unfortunate in the ewe. This was also demonstrated in this study since 2 of these ewes had a complicated parturition, where both the ewes and the lambs died.

On the basis of the results obtained in this study, immunization of older ewes of the Dala breed in order to increase lambing rate can not be recommended. Immunization of young ewes will increase the proportion of twins, but an increase in triplets would also be expected. This must be considered before immunization of young ewes can be recommended.

\section{References}

Anonymous: Husdyrkontrollen i Norge 1986. Landsrådet for husdyrkontrollen, Oslo 1987. (Sheep recording in Norway in 1986. Norwegian National Board of Animal Productivity Recording. Oslo 1987).

Geldard H: Field evaluation of Fecundin, an immunogen against androstenedione. Proc. Aust. Soc. Anim. Prod. 1984, 15, 185-191.

Geldard H, Scaramuzzi RJ, Wilkins JF: Immunization against polyandroalbumin leads to increases in lambing and tailing percentages. N.Z. vet. J. 1984, 32, 2-5.

Hanrahan JP, Quirke JF: The effect of immunization against steroids on ovulation rate in the ewe. In: Roche JF, O'Callaghan D (eds). Follicular growth and ovulation rate in farm animals. Martınus Nijhoff Publishers, Dordrecht 1987, p. 135-150.

Scaramuzzi RJ: Antibodies to androgens, and ovulation in the ewe. J. Steroid Biochem. 1979, 11, 957-961. 
Scaramuzzı RJ, Davıdson WG, Van Look PFA: Increasing ovulation rate in sheep by active immunisation against an ovarian steroid androstenedione. Nature (Lond.) 1977, 269, 817-818.

Smith JF: Immunisation of ewes against steroids: A review. Proc. N. Z. Soc. Anim. Prod. 1985, 45, 171-177.

\section{Sammendrag}

Effekt av aktıv immuniserıng av søyer mot androstendion på antall fødte lam og på lammeavdrått.

Aktiv immunisering av søyer av Dala rase mot an- drostendion førte til en gjennomsnittlig økning i antall fødte lam (levendefødte og dødfødte) med 0.29 lam (p <0.01). Hos ett år gamle immuniserte søyer var økningen 0.43 lam ( $p<0.01$ ) og hos eldre søyer 0.23 ( $p<0.1$ ). Hos immuniserte eldre søyer var det en sterk økning i antall dødfødte lam. Fem av de immuniserte eldre søyene hadde firlinger mens ingen søye i kontrollgruppen hadde mer enn 3 lam.

Hos ett år gamle immuniserte søyer var den midlere lammeavdråtten $11.3 \mathrm{~kg}$ høyere enn hos kontrolldyr. Denne forskjellen var imidlertid ikke signifikant ( $p$ $<0.1)$.

(Received August 10, 1988; accepted February 3, 1989).

Reprints may be requested from: $\varnothing$. Andresen, Department of Reproduction and Forensic Medicine, Norwegian College of Veterinary Medicine, Post Box. 8146 Dep., N-0033 Oslo 1, Norway. 
